\title{
Problems and Countermeasures of regional economic cooperation in Northeast Asia
}

\author{
Danlin Li \\ Jilin Business And Technology College, Jilin, China \\ 16205918@qq.com
}

Keywords: Northeast Asia. Economic development; cooperation

\begin{abstract}
In recent years, the northeast Asia countries to push forward economic development zone construction, all kinds of growing bilateral economic cooperation, sub-regional economic cooperation and development is rapid, sustainable development of northeast Asia regional economic cooperation. However, regional cooperation in northeast Asia also faces many constraints, such as regional security issues, differences in economic development levels and U.S. containment. In the long run, only fully excavate the potential of northeast Asia, makes resolving various constraints, can make the regional economic cooperation to a new level, and occupy more important position in the world economy.
\end{abstract}

\section{Introduction}

Northeast Asia is one of the most important and developing regions in the global economy. The combined GDP of northeast Asia accounts for 20 percent of the world economy. The combined GDP of China, Japan and South Korea accounts for about 70\% of Asia's GDP. Although it was once affected by the Asian financial crisis, northeast Asia is still the most promising region in the world. Now with the speeding up of economic globalization, on the basis of the geopolitical relations increasingly strengthen regional economic cooperation, northeast Asian region in Asia and even the status and role in the development of global economy will also be more important.

\section{The present situation of regional economic cooperation in northeast Asia}

The regional cooperation body of northeast Asia is China, Japan and the rok. Cooperation and exchanges have entered a new stage. Since the trilateral leaders' meeting in 2008 was conducted under the framework of "10 + 3", the trilateral cooperation has been deepened. For planning for medium and long-term cooperation in 2010, China, South Korea and Japan respectively published "trilateral cooperation outlook 2020", "about building the trilateral cooperation secretariat in the memorandum, just three countries to promote science and technology, economic and cultural exchanges, promote the sustainable development, and strengthen communication and coordination on international and regional issue come to an agreement. In 2012, the fifth leaders' meeting in Beijing issued a joint declaration on the promotion of all-round partnership. To date, the three countries have established 18 ministerial conference mechanisms and more than 50 exchange platforms in the fields of diplomacy, science and technology, environmental protection, tourism, water resources and agriculture.

\section{Problems of economic cooperation in northeast Asia}

The northeast Asian economy has a vigorous development trend, but there are still a lot of adverse factors.

(a) there are significant differences in the social and political systems in the region

In addition to South Korea and north Korea, all other northeast Asian countries have their own language systems, and the language differences hinder the smooth development of regional 
cooperation. From the political system, political system also varies greatly from country to country in northeast China, is not conducive to the formation of common values and cohesion and build in northeast China, which makes the regional cooperation the lack of a solid social foundation. In addition, the northeast Asian countries have long had various political differences, especially historical feuds, territorial disputes and territorial sea disputes, which have seriously hampered the smooth progress of regional economic cooperation. The uncertainty of the Korean nuclear issue will inevitably affect the process of regional economic cooperation in northeast Asia.

(b) The economic development of all countries is uneven and the economic system is different

According to world bank statistics, among the nations of northeast Asia area, gross domestic product has reached thousands of times, the biggest gap and gap between Germany and Portugal in the European Union are 16.5 times, however, the gap between the north American free trade area and Mexico is only 27.8 times. It is generally believed that the establishment of a high-level regional economic group should have four conditions, one of which is that the per capita GNP should be similar. Northeast Asia power and output per capita level difference, this to coordinate the relationship between countries, seek a is beneficial to gradually narrow the gap between countries and conforms to the national interests of the effective ways to cooperate more difficult. There are also obvious differences in the economic system and the degree of marketization of the countries in the region, and the market economic order in the whole region has not been established. Due to lack of market economic order, and that the economic activity in all countries of the region did not run according to the market order and international common practice, and the original interaction between different economic order and economic activities are difficult to smooth docking.

(c) the United States has highlighted the diversities of economic cooperation in northeast Asia

In order to maintain its vested interests in the region, the us has actively participated in the game of great power interests with its alliance with Japan and South Korea, and has increased the complexity of regional cooperation in northeast Asia. In recent years, the United States by participating in and dominate the trans-pacific partnership agreement negotiations, tries to capture the future has enormous development space in the asia-pacific region, to prevent China and Japan in east Asia to establish a similar "east Asian economic integration organizations, to protect their own political and military position in the region. At the same time, the northeast Asian countries have strong economic ties with the United States. The United States is the main export market of northeast Asian countries and plays an important role in the trade of the United States in the countries of northeast Asia. Economic cooperation in northeast Asia is difficult to avoid the interference of American factors.

\section{Countermeasures to promote regional economic cooperation in northeast Asia}

In the face of the present situation of economic cooperation and the existence of various constraints in northeast Asia, we believe that it is important to promote the in-depth development of regional economic cooperation in northeast Asia from the following aspects.

(a) Promote the establishment of the china-japan-rok free trade area as soon as possible

With the advent of the era of after the financial crisis, the establishment and further development of regional economic group, increasingly become the main trend of world economic integration, and become the fight against the financial risk, to resolve the main body of the economic crisis. According to world bank development report of the world economy in 2003, the GDP is located in the top 30 countries and regions all over the world, there are 25 countries and regions has become a regional free trade agreement or customs union members, not only five countries and regions, namely, China, Japan, South Korea, Taiwan and Hong Kong, China. If the three countries to establish a free trade area, will become and the European Union and north American regions of the world's third largest free trade area, greatly promote the asia-pacific region and the development of the sub-regional economic cooperation in northeast Asia. China is the earliest country, China, Japan and South Korea free trade area is put forward on the basis of the three years of joint research, 2010, the three governments will research the feasibility of establishing a free trade zone, and opened at 
the end of 2012 the three investment agreement. The signing of the investment agreement will provide the basis for further negotiations based on a fully open tripartite free trade area.

(b) Drawing on asean's experience to accelerate the establishment of a regional cooperation mechanism in northeast Asia

At present, the cooperation mechanism of northeast Asia is not yet established, and it is necessary to step up the process of institutionalizing cooperation in northeast Asia. But due to the northeast Asian countries, especially China, South Korea and Japan there is a certain historical grievances, especially between China and Japan, Korea and Japan bitterness deeper, long-term lack of political trust between the government, domestic nationalism is widespread, and the establishment of regional cooperation mechanisms there are serious political and security barrier. We can consider economic cooperation as the main axis, and selectively promote various cooperation. On cooperation framework and method can be use for reference the experience of the association of south-east Asian nations (asean), first in the northeast Asia region to carry out the "3 +3 " talks and dialogue, actively promote the ministerial dialogue open, drive higher levels of talks and dialogue, with cooperation initiative, enhance dialogue level, eventually led to the establishment of the northeast Asia summit mechanism.

(c) Actively explore new areas of cooperation

In the post-financial crisis era, the world economy entered into a period of deep adjustment. After the virtual economic bubble burst, the world's major economies began the process of reindustrialization, the new technological revolution and industrial revolution, which made major changes in the international industrial landscape. In this context, China, Japan and South Korea, as the major economies in northeast Asia, need to look at future development and jointly seek cooperation and development in the field of emerging growth. China, Japan and the rok should strengthen exchanges and cooperation in the fields of new energy, clean technology, biological resources, environmental protection and exploration and development of seabed resources.

Today, cooperation in northeast Asia still faces many difficulties and uncertainties. North and south of the Korean peninsula, Japan, Korea and Japan around the island's sovereignty dispute continuously, and have power to participate in the game of the complexity of the northeast Asian region, international relations in northeast Asia regional cooperation in the future. However, we must also see that the deepening and development of regional economic cooperation in northeast Asia is an irresistible trend and a necessity for northeast Asia to seek its own security and development. Regional cooperation without political and security guarantees is difficult to deepen, and countries in northeast Asia should establish political trust mechanisms as soon as possible. Individual countries should, in addition to the issue of territorial disputes, face the right of history, and should cease their irresponsibility on issues of human morality and rights such as comfort women. Only on the basis of mutual respect and trust can we strengthen the establishment of political and security mechanisms in northeast Asia and promote the smooth development of regional economic cooperation in northeast Asia.

\section{References}

[1] Usher in new globalization with "One Belt And One Road", [J].Qiaobin Fing, Chinese finance, 2017(12).

[2] The change and trend of china-russia economic cooperation in the new situation,[J].Jing Jiang,2017(05). 